\title{
Collective Bargaining
}

\section{by C. James Schmidt \\ University Librarian \\ Brown University}

In 1976, CbRL Neus published a review of decisions of the National Labor Relations Board affecting academic librarians in private colleges and universities." This review concluded that the NLRB had, when faced with the question, consistently ruled that librarians in academic libraries had a functional affinity with faculty and therefore should be included in bargaining units with other

"College \& Research Libraries News 37:1-2 (Jan. 1976).

teaching faculty. Although the jurisdiction of the NLRB is limited to private institutions of higher education, its reasoning is often followed by state agencies having jurisdiction over public colleges and universities.

Since 1977, the number of campuses organized seems to have remained static. Thus it seems appropriate to review bargaining-unit configurations as they affect academic librarians in public and private institutions. Table 1 names specific institutions for illustrative purposes only but is not intended to be exhaustive. Furthermore, it reflects only four-year institutions. Information was current as of May 1979

TABLE I

Collective Bargaining in Four. Year Institutions AND ACADEMIC LibRaRIans. BaRGaINING UNIT VaRIaTIONS

\begin{tabular}{|c|c|c|}
\hline & \multicolumn{2}{|c|}{ Control } \\
\hline Scope of Bargaining $\mathrm{C}^{\prime}$ nit & Public & Private \\
\hline Librarians only & None & Boston, Brandeis \\
\hline Librarians witn library clerks & None & Claremont ${ }^{1}$ \\
\hline Library clerks only & None & Brown, Columbia \\
\hline Librarians with faculty & $\begin{array}{l}\text { Hawaii, N.J. State } \\
\text { Colleges, Pa. State } \\
\text { Colleges, CUNY, } \\
\text { Wayne State }\end{array}$ & Adelphi, NYU ${ }^{2}$ \\
\hline Librarians with nonteaching professionals & $\begin{array}{l}\text { U. of Maine, U. of } \\
\text { Connecticut } \\
\text { Florida System }\end{array}$ & None \\
\hline $\begin{array}{l}\text { Librarians with faculty and with } \\
\text { nonteaching professionals }\end{array}$ & SUNY & None \\
\hline
\end{tabular}

1. Nonsupervisory librarians elected to be included in a unit with library clerks. See 196 NLRB 121 (1972).

2. No agent was certified by vote, but the composition of the unit as determined by the NLRB did include librarians with the faculty. 205 NLRB $16(1973)$

\section{Continuing Education Opportunities}

The following continuing education activities have been listed with ACRL's Continuing Education Clearinghouse. If your organization is sponsoring an activity that you think may be of interest to ACRL members, please send the pertinent details to the ACRL Office, $50 \mathrm{E}$. Huron St., Chicago, IL 60611

\section{October}

25-Micrographics: Preconference Workshop on Micrographics, Ontario College and University Library Association, Harbour Castle Hilton Hotel, Toronto. Fee: $\$ 25$ for Ontario Library Association members, $\$ 35$ for nonmembers, $\$ 15$ for students. Contact: Jean Weihs, Seneca College, 1750 Finch Ave., E., Toronto.

\section{November}

6-Data bases: Nonbibliographic On Line Data Base Services, seminar, Cuadra Associates, Atlanta, Georgia. Fee: $\$ 115$ in advance, $\$ 135$ if invoiced. Contact: Carlos A. Cuadra, 1523 Sixth St., Suite 12, Santa Monica, CA 90401, (213) 415-0644

\section{December}

10-12-Space: "Space Planning and Practical Design for Librarians," seminar, Aaron Cohen and Associates, New York City. Fee: $\$ 200$. Contact: Aaron Cohen, Teatown Road, Croton-onHudson, New York, NY 10520; (914) 271-8170, (212) 689-8138. 